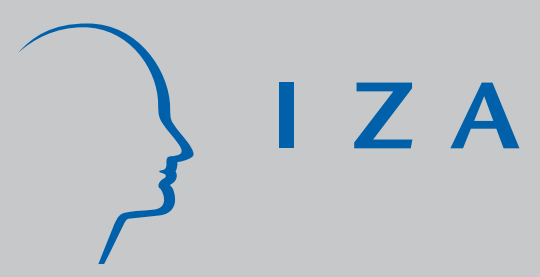

IZA DP No. 1780

The Demand for Labor: An Analysis Using Matched Employer-Employee Data from the German LIAB. Will the High Unskilled Worker Own-Wage Elasticity Please Stand Up?

J ohn T. Addison

Lutz Bellmann

Thorsten Schank

Paulino Teixeira

September 2005 


\title{
The Demand for Labor: An Analysis Using Matched Employer-Employee Data from the German LIAB. Will the High Unskilled Worker Own-Wage Elasticity Please Stand Up?
}

\author{
John T. Addison \\ University of South Carolina, \\ Universidade de Coimbra/GEMF and IZA Bonn \\ Lutz Bellmann \\ Institute for Employment Research (IAB), \\ University of Hannover and IZA Bonn
}

Thorsten Schank

University of Erlangen-Nuremberg

Paulino Teixeira

Universidade de Coimbra

Discussion Paper No. 1780

September 2005

\author{
IZA \\ P.O. Box 7240 \\ 53072 Bonn \\ Germany \\ Phone: +49-228-3894-0 \\ Fax: +49-228-3894-180 \\ Email: iza@iza.org
}

Any opinions expressed here are those of the author(s) and not those of the institute. Research disseminated by IZA may include views on policy, but the institute itself takes no institutional policy positions.

The Institute for the Study of Labor (IZA) in Bonn is a local and virtual international research center and a place of communication between science, politics and business. IZA is an independent nonprofit company supported by Deutsche Post World Net. The center is associated with the University of Bonn and offers a stimulating research environment through its research networks, research support, and visitors and doctoral programs. IZA engages in (i) original and internationally competitive research in all fields of labor economics, (ii) development of policy concepts, and (iii) dissemination of research results and concepts to the interested public.

IZA Discussion Papers often represent preliminary work and are circulated to encourage discussion. Citation of such a paper should account for its provisional character. A revised version may be available directly from the author. 


\section{ABSTRACT}

\section{The Demand for Labor: An Analysis Using Matched Employer- Employee Data from the German LIAB. Will the High Unskilled Worker Own-Wage Elasticity Please Stand Up?*}

This paper uses matched employee-employer LIAB data to provide panel estimates of the structure of labor demand in Germany, 1993-2002, distinguishing between highly skilled, skilled, and unskilled labor and between the manufacturing and service sectors. Reflecting current preoccupations, our demand analysis seeks also to accommodate the impact of technology and trade in addition to wages. The bottom-line interests are to provide elasticities of the demand for unskilled (and other) labor that should assist in short-run policy design and to identify the extent of skill biases or otherwise in trade and technology.

JEL Classification: F15, J23, J31, O33, F15

Keywords: labor demand, own-wage/cross-wage elasticities, trade, technology, organizational change, linked employee-employer data, panel estimates

Corresponding author:

John T. Addison

Department of Economics

Moore School of Business

University of South Carolina

1705 College Street

Columbia, SC 29208

USA

Email: ecceaddi@moore.sc.edu

\footnotetext{
* A shorter version of this paper was presented at the Department of Trade and Industry/Policy Studies Institute Workshop Making Linked Employer-Employee Data Relevant to Policy Making (London, September 16, 2005). The authors thank, without implicating, participants for their helpful comments.
} 


\section{Introduction}

For several decades now, the demand for unskilled labor in Germany as elsewhere has been declining. There is no shortage of explanations for this phenomenon: skill-biased technological change (Falk and Seim, 1999), increased international trade (Fitzenberger, 1999a) and, latterly, organizational change (Lindbeck and Snower, 2000; Fitzenberger, 1999b). (A related preoccupation is of course the extent to which declining demand for the unskilled has been exacerbated by a rigid wage structure.) In the present treatment, using information on 1,171 manufacturing plants employing on average 360,000 employees, and on 174 service sector establishments covering some 49,000 employees, we seek to address these various influences using a flexible cost function framework to derive the demand for heterogeneous labor It is precisely this latter complication that involves the use of linked employee-employer data because only the latter contain detailed wage information. We estimate inter al. the own-wage elasticity of unskilled and skilled (and highly skilled) labor as well as the elasticities of the various labor categories with respect to trade, technology, and organizational change measures. We disaggregate by manufacturing and services both because of sectoral differences in the role of trade and by reason of occupational composition.

To anticipate our findings, which are somewhat at odds with the literature, we report that the own-wage elasticity of unskilled labor in manufacturing, although well determined, is smaller in absolute value than that of skilled workers (if not the most highly skilled). We also find that trade and technology are not unfavorable to unskilled worker employment, while organizational change which is often assumed to be destructive of unskilled jobs also appears to have a positive effect. To explain why unskilled worker employment has shrunk, we would therefore rely on (excessive) unskilled worker wage levels in a rigid wage system, even if the actual decline in employment over the decade long sample period is muted. 


\section{Data}

Our data are taken from ten waves of the LIAB, 1993-2002. The LIAB combines Federal Employment Agency (Bundesagentur für Arbeit) employment statistics with plant-level data from the Institute for Employment Research (Institut für Arbeitsmarkt- und Berufsforschung) or IAB Establishment Panel. The distinctive feature of the LIAB is the combination of information on individuals and details concerning the firms - strictly establishments - that employ them. The employment statistics are drawn from the German employment register, which contains information on all employees and trainees subject to social security taxes (see Bender, Haas, and Klose, 2000). In 1995, for example, the employment statistics covered 79.4 (86.2) percent of all employed persons in Western (Eastern) Germany. Those excluded, in addition to the self employed, include civil servants, family workers, students enrolled in higher education, and workers in marginal employment. The employment register was established in 1973 to integrate the notification procedures for social security (pensions, health insurance, and unemployment insurance). Information is recorded at the start and end of the individual's employment within a firm and in annual end-year reports. The employment statistics contain data on the individual's three-digit occupation, daily gross wage up to the earnings ceiling for social security contributions, ${ }^{1}$ gender, year of birth, nationality, marital status, number of children, and schooling/training. Each individual record also contains the establishment identifier, as well as the size and industry affiliation of that establishment, although unfortunately one cannot match establishments belonging to a single enterprise.

The plant-level component of the LIAB, the IAB Establishment Panel, ${ }^{2}$ was initiated in 1993 (Kölling, 2000). It is based on a stratified random sample - strata for 16 industries and 10 employment size classes - from the population of all establishments. (Although larger plants are over-sampled, within each cell the sampling is random.) In 1993 the sample comprised 4,265 plants, accounting for 0.27 percent of all plants in West Germany and 11 percent of total employment (29 million employees). Subsequently in 1996 the former GDR 
was administered the Panel survey, with 4,313 establishments (or 1.1 percent of all plants) and 11 percent of total employment (6 million). Since then the number of plants sampled has steadily increased to facilitate analysis at Länder level; for example, in 2003 the unified sample contained some 15,857 plants.

For its part, the IAB Establishment Panel was created to meet the need of the Federal Employment Agency to provide further and detailed information on the demand side of the labor market. Accordingly, information on the workforce, its decomposition, and development through time are central elements of the Panel questionnaire. Further questions concern establishment sales, exports, and investment, technological status, age, corporate form and legal status, as well as the size of the overall wage bill, training provision, working time, reorganization measures, and aspects of collective bargaining. Most such questions are asked annually. One exception is organizational change. The question pertaining to those organizational changes introduced in the last two years was included in four surveys only, namely, 1995, 1998, 2000, and 2001. ${ }^{3}$ Other examples cover topics such as innovations, profit sharing/share ownership, further training, and labor flexibility.

In summary, the LIAB is created by linking the employment statistics of the Federal Labor Agency with the IAB Establishment panel via the plant identifier available in both data sets. This matched data set currently comprises the years 1993 through 2002. For the purposes of the present inquiry and in the interests of panel estimation we use information on all ten years and thus exclude Eastern Germany. The basis of the initial sample is all establishments in the manufacturing sector, while for services we excluded banking and insurance where output is not measured by sales (being reported in balance-sheet terms for the former and in premiums for the latter) plus three clearly not-for-profit service subsectors (e.g. public administration). We then proceeded to weed out further nonprofit organizations in services by exploiting (two) other questions in the Establishment Panel so as to obtain our preferred services (sub)sample. ${ }^{4}$ 


\section{The Model}

Our theoretical framework admits of a representative firm that chooses among heterogeneous labor inputs while allowing for unrestricted factor substitution. Any disaggregation of the required production inputs is nevertheless limited by data availability on the relevant subaggregates as well as reliable information on the respective input prices. Unsurprisingly, in empirical applications disaggregation is more determined by pragmatism than by anything else.

In our case, workers were notionally classified into six skill categories - three bluecollar and three white-collar - prior to using the individual (administrative) records and matching them to the production units from the establishment panel. So as to avoid having too few workers in the individual skill categories for our two sectors, we actually classified workers into four categories per sector - as well as imposing a minimum requirement of two workers per skill group. For manufacturing this meant three blue-collar skill categories (unskilled, skilled, and highly skilled [i.e. master craftsmen]) and one composite white-collar group, based on employer definitions. For services this meant three white-collar skill categories (unskilled, skilled, and highly skilled, now defined on the basis of education level and qualifications) and a composite blue-collar entity. ${ }^{5}$

Given this representation of the structure of the workforce, we wanted the substitution possibilities between the various types of labor to be as unrestricted as possible. To this end, we deployed a flexible cost function - specifically, the Generalized Leontief Function - in which the elasticity of substitution between any pair of factors can assume any (positive) value; indeed, the greater is the corresponding coefficient in the cost function, the greater is the elasticity of substitution (Diewert, 1971). ${ }^{6}$

In this framework we treat capital as a quasi-fixed factor. This assumption means that we are only concerned with the optimal choice of the set of variable inputs, therefore using the capital stock as a regressor in our heterogenous labor demand functions rather than its user 
cost. $^{7}$ We think this treatment of capital is appropriate given the data circumstances. Although the maximum panel length is ten years, in many cases establishments are only observed for a few years. Furthermore, there is no direct measure of the capital stock: it can only be proxied using information on annual investment. The undoubted limitations of our measure of the capital stock are in part offset by a number of technological variables in the panel; for example, dummy variables indicating the use of either state-of-the art or up-to-date equipment, recent investments in information and communication technology, inter al., and the introduction of organizational changes. These arguments will be used to evaluate the impact of technological changes on heterogeneous labor demand developments (as they are all treated as exogenous, we will only be able to measure their scale effects). ${ }^{8}$

Formally, omitting establishment and time subscripts, the selected Generalized Leontief technology (cost function) can be denoted as $C(W, y, Z ; \alpha, \beta, \gamma)$, where $W=\left(w_{1}, w_{2}, w_{3}, w_{4}\right)$ is the vector of variable input prices, $y$ is output, $Z=\left(z_{1}, z_{2}, z_{3}\right)$ is a column vector of non-wage variables comprising the capital stock $\left(z_{1}\right)$, the export share $\left(z_{2}\right)$, and a technology indicator $\left(z_{3}\right)$; and $(\alpha, \beta, \gamma)$ are the parameters to be estimated.

In particular, we specify the cost function

$$
C(W, y, Z ; \alpha)=y \sum_{i=1}^{4} \sum_{j=1}^{4} \alpha_{i j} w_{i}^{0.5} w_{j}^{0.5}
$$

and then enter additively the exogenous variables in vector $Z$, plus a quadratic term in output to allow for non-constant returns to scale, as follows

$$
C(W, y, Z ; \alpha, \beta, \gamma)=y \sum_{i=1}^{4} \sum_{j=1}^{4} \alpha_{i j} w_{i}^{0.5} w_{j}^{0.5}+y^{2} \sum_{i=1}^{4} \beta_{i} w_{i}+\sum_{i=1}^{4} \sum_{k=1}^{3} \gamma_{i k} w_{i} z_{k}
$$

In fact, we disaggregate the variable $z_{3}$ into $z_{31}, z_{32}, z_{33}$, and $z_{34}$, denoting the presence of state-of-the-art or up-to-date equipment, investments in information and communication technology, investments in buildings, and investments in production units, respectively. And 
in a final empirical specification for manufacturing we will also include an additional regressor flagging recent organizational change.

The corresponding vector of conditional factor demands, obtained by applying Shephard's Lemma, is then given by $X=\left(x_{1}, x_{2}, x_{3}, x_{4}\right)$, where $x_{i}$ is the conditional factor demand of skill group $i$. A useful property of the Generalized Leontief cost function is that the corresponding conditional demand functions are also linear in the parameters. A typical labor demand $x_{i}$ will be

$$
x_{i}=x_{i}(W, y, Z ; \alpha, \beta, \gamma), \quad i=1,2,3,4 .
$$

Then, differentiating the cost function (2) with respect to $w_{i}$, we obtain

$$
x_{i}(W, y, Z ; \alpha, \beta, \gamma)=y \alpha_{i i}+y \sum_{i \neq j} \alpha_{i j} w_{i}^{-0.5} w_{j}^{0.5}+\beta_{i} y^{2}+\sum_{k=1}^{3} \gamma_{i k}{ }_{k} .
$$

Although these four demand functions can be estimated by OLS, there are well known gains in efficiency if they are estimated jointly in a system of seemingly unrelated regressions (the SUR model), allowing for the possibility that the error terms in each specification in equation (4) are contemporaneously correlated (e.g. unexpected shocks are expected to affect them in a systematic way). In particular, we will implement a SUR model with fixed effects, which amounts to applying a standard within transformation of the data (which means that for each variable we take the difference from the mean of the corresponding production unit). The usual symmetry conditions are also imposed to the system. Further, to avoid any bias in the estimated standard errors, the labor demand input is divided by output so that the system is specified in terms of input/output coefficients.

Finally, the relevant own- and cross-wage elasticities, as well as the elasticities of labor demand with respect to capital and the other indicators of technology, can be derived as follows. Formally, the elasticity of the labor demand for skill group $i$ with respect to input price $j$ is given by 


$$
\eta\left(x_{i}, w_{j}\right)=\left(\partial x_{i} / \partial w_{j}\right)\left(w_{j} / x_{i}\right), i, j=1,2,3,4
$$

which, using (4), yields the own-wage elasticity

$$
\eta\left(x_{i}, w_{i}\right)=\left(-0.5 y * \sum_{j \neq i} \alpha_{i j} w_{j}^{0.5}\right) /\left(x_{i} w_{i}^{0.5}\right)
$$

For its part, the cross-wage elasticity is given by

$$
\eta\left(x_{i}, w_{j}\right)=\left(0.5 y * \alpha_{i j} w_{j}^{0.5}\right) /\left(x_{i} w_{i}^{0.5}\right) .
$$

Clearly, if the cross-wage elasticity between $i$ and $j$ is positive (negative), the corresponding skill groups are substitutes (complements).

In turn, the output elasticity is

$$
\eta\left(x_{i}, y\right)=y\left(\alpha_{i i}+\sum_{j \neq i} \alpha_{j} w_{j}^{0.5} w_{i}^{-0.5}+2 \beta_{i} y\right) / x_{i}
$$

while the elasticity with respect to any of the $z_{i}$ variables (i.e. capital, export share, and technology) is

$$
\eta\left(x_{i}, z_{i}\right)=\gamma_{k} z_{i} / x_{i}
$$

(For the dichotomous $z_{3}$ technology variables, the semi-elasticity is obtained by dividing the corresponding elasticity in (9) by $z_{31}, z_{32}, z_{33}$, and $z_{34}$, respectively.)

We anticipate that the own-wage elasticities should not only be negative but also decrease (in absolute value) with the skill content of the labor input, while the capital stock is expected to evince greater complementarity with highly skilled workers. We also anticipate that technological and organizational change might impact labor, and in particular unskilled labor, unfavorably and (for manufacturing) that any adverse trade effects would likely be confined to be unskilled workers. 


\section{Empirical Specification}

Based on equation (4), the system of employment/output ratios is given by

$$
x_{i} / y=\alpha_{i i}+\sum_{i \neq j} \alpha_{i j} w_{i}^{-0.5} w_{j}^{0.5}+\beta_{i} y+\sum_{k=1}^{3} \gamma_{i k} z_{k} / y+e,
$$

where $e$ denotes the error term. Or, setting $x^{\prime}{ }_{i}=x_{i} / y, z^{\prime}{ }_{k}=z_{k} / y$ (since it seems reasonable that the error variance of the skill groups is correlated with the output level) and adding the subscripts $l$ and $t$ for establishment and year, respectively, we have

$$
x^{\prime}{ }_{i l t}=\alpha_{i i}+\sum_{i \neq j} \alpha_{i j} w^{\prime}{ }_{j l t}+\beta_{i} y_{l t}+\sum_{k=1}^{3} \gamma_{i k} z^{\prime}{ }_{k}+e_{i l t},
$$

with $w_{j}^{\prime}=\left(w_{j} / w_{i}\right)^{0.5}$.

To control for unobserved, time-invariant establishment effects, we apply the within transformation of equation (11), as follows

$$
x^{\prime}{ }_{i l t}{ }^{-\bar{x}^{\prime}}{ }_{i l}=\sum_{i \neq j} \alpha_{i j}\left(w^{\prime}{ }_{j l t}-\bar{w}^{\prime}{ }_{j l}\right)+\beta_{i}\left(y_{l t}-\bar{y}_{l}\right)+\sum_{k}^{3} \gamma_{i k}\left(z_{k l t}{ }^{-\bar{z}^{\prime}}{ }_{k l}\right)+\varepsilon_{i l t},
$$

where a bar over the variable denotes a mean over time. As was noted earlier, we estimate the four factor demand functions (per sector) in equation (12) by the Seemingly Unrelated Regression (SUR) method.

We have already described the basis of construction of the four labor inputs in each of our two sectors, manufacturing and services. Also taken from the employment statistics are input prices since the establishment panel only contains information on the overall wage bill. It will be recalled that the earnings variable in the administrative data is censored at the maximum earnings taxable under social security. In manufacturing (services), 7.75 (8.56) percent of the wage observations were censored. We therefore used a Tobit-type estimator to impute daily earnings values for those with right-censored earnings for each skill group separately, estimating eight wage equations using pooled data and time dummies. ${ }^{9}$ Predicted wages together with the corresponding actual (below-ceiling) wages were used in the 
calculation of mean wages per skill group per plant per year. For manufacturing, the total number of observations were as follows (with the censored values in parentheses): blue-collar unskilled, 2,626,147 (6,848); blue-collar skilled, 2,296,841 (18,763); blue-collar, highly skilled 185,083 (31,856); white-collar composite, 2,330,451 $(519,904)$. For services, the corresponding totals were: white-collar unskilled, 99,296 (2,642); white-collar skilled, 1,729,792 (117,505); white-collar highly skilled, 454,763 (140,556); blue-collar composite, 796,786 (2,964). The variables included in our conventional earnings function are detailed in Appendix Table 1 and the fitted equations are available from the authors upon request. Not mentioned in the table is our imposition of a monthly wage cutoff of DM 1,000, although as a practical matter this restriction resulted in the loss of few observations because of the 'prior' exclusion of part-time workers.

These plant specific wage measures, together with the corresponding number of employees, ${ }^{10}$ are added to the establishment panel, which contains the other information needed to estimate the system of input-output ratios from which our elasticities are derived. Our measure of output is sales volume. It would have been preferable to use a value-added measure of output, obtained by subtracting the cost of materials from sales. Although the establishment panel allows us to construct a value-added measure ${ }^{11}$ - and a number of recent studies have deployed this measure (see, for example Wolf and Zwick, 2002) - inspection of the raw data reveals that the materials cost estimates are little more than informed guesstimates. No less important, panel survey respondents often fail to answer the materials cost question, so that use of a value-added measure involves a large reduction in the number of observations: around one-third of all plants have missing values for these intermediate inputs.

The next variable taken from the establishment panel is our measure of the capital stock. This argument is approximated by the sum of investment expenditures in the last two years and like the output measure is also calculated in DM million. In other work, two of the 
present authors have used replacement investment since this variable is more clearly expected to be proportional to the capital stock (see Addison, Schank, Schnabel, and Wagner, 2003). In the present paper, however, our sample period begins in 1993 and data on replacement investment is only available after 1996.

The penultimate four arguments are dummy variables and provide more information on the nature of the capital stock. Three investment dummies signify whether a plant has, in the previous year, invested in property and buildings, in production units, and in information and communication technology. Supplementing the last measure as a proxy for the use of new technologies in the plant is a separate dummy variable set equal to one if the plant uses either state-of-the art or at least up-to-date equipment to produce goods and services. ${ }^{12}$ For manufacturing alone, we also include an indicator of organizational change over the previous two years. This variable, which is not available for all years in the sample, is defined in Appendix Table 1 and footnote 3.

Our final argument is a continuous variable proxying the importance of international trade and globalization. It is the proportion of sales consisting of exports. Like the organizational change variable is only entered for the manufacturing sector. Descriptive statistics on all variables are provided in Tables 1 and 2.

(Tables 1 and 2 near here)

\section{Findings}

Tables 3 and 4 report the parameter estimates of equation (12) for manufacturing and services, respectively. The impact on demand of all variables, other than wages and output, can be directly read from the coefficient estimates. And we can infer from the relative wage coefficients which inputs are complements and which are substitutes in producion. In each case, however, we will dicuss these relationships in terms of the respective elasticities given in Tables 5 and 6. 
(Tables 3 and 4 near here)

Beginning with the results for manufacturing in Table 5, therefore, we see that with the exception of the white-collar composite group, the own-wage elasticities are all of the expected sign, and those of unskilled workers and skilled workers are both well determined and the differences between them (and between them and the white-collar composite) are also statistically significant at the .05 level or better. Note, however, that our expectation that the absolute value of the unskilled elasticity would be larger than those of the other skill groups is not borne out. Unskilled blue-collar workers emerge as substitutes in production for skilled and highly skilled workers but not with white-collar workers as a collectivity. On the other hand, skilled and highly skilled workers are weakly complementary. As far as white-collar workers are concerned the only significant cross elasticity is as noted earlier the negative association with unskilled blue-collar workers.

(Table 5 near here)

With the exception of white-collar workers, the output elasticities are positive and statistically significant. They are well determined only for the skilled blue-collar worker category and the white-collar aggregate (although the latter association is perverse). The labor demand elasticities with respect to capital are uniformly well determined and of very similar magnitude for each of the blue-collar groups. And trade seems benign in the sense that a rising share of exports in total sales seemingly boosts labor demand throughout. But the effect is small for blue-collar workers: a 10 percent increase in export share is associated with a less than one percent increase in employment. For white-collar workers the growth in employment is anomalous - on this occasion, anomalously high.

The generally benign effect of exports has a counterpart in the influence of technology. For both measures - state-of-the-art/up-to-date technical equipment and investments in information technology - the semi-elasticities are all positive and well determined. For each labor category, upgrading to state-of-the-art equipment and going from 
no investment to some investment in IT has a positive, albeit still small effect on employment. We have no explanation for the consistent but opposing directional effects of investment in other production units (positive) on property and buildings (negative) on labor demand.

(Table 6 near here)

Turning to the results for services in Table 6, perhaps the main difference from manufacturing is the emergence of a hierarchy in the pattern of own-wage elasticities. In particular, the own-wage elasticity of unskilled white-collar workers is strongly negative - a 10 percent increase in the wage of unskilled white collar employees lowers their employment by 21 percent - and is clearly differentiated from the experience of the two more skilled white-collar groups, the estimates for both of which groups are poorly determined. The ownwage elasticity of the blue-collar aggregate is also strongly negative and not significantly different from that of unskilled white-collar workers. There are few indications of either complementarity or substitutability between unskilled white-collar workers and their more skilled counterparts, although the skilled and the very highly skilled are clearly complementary inputs. Increases in the wages of blue-collar workers as a group lead to increases in both unskilled and skilled (although not highly skilled) white-collar employment.

Labor demand elasticities with respect to output for unskilled white-collar employees and blue-collar workers exceed unity and are well determined. Those for the two other whitecollar categories are statistically insignificant. But, as was the case for manufacturing, there is strong evidence of complementarity between capital and labor. Similarly, technology is associated with increased employment. In fact, the semi-elasticities are somewhat stronger than observed for manufacturing in seven out of eight cases. Again, then, investing in IT and upgrading technology leads to increases rather than decreases in labor inputs. As far as labor demand elasticities with respect to investments in other production units and in property and buildings are concerned there is some reversal of findings: now the latter investments increase 
employment across the board while the former investments tend to reduce employment albeit very modestly.

(Table 7 near here)

Finally, we investigated the effects of organizational change on labor demand. We already noted the loss in observations that this caused (because of the irregularity with which this question is asked in the panel survey) and so we only present results for the considerably larger manufacturing sample. We simply add the new regressor to an otherwise unchanged specification for manufacturing. As before the respective elasticities are provided. As can be seen from Table 7, the main result is of course that the introduction of organizational change is associated with increases in employment. The magnitudes of the semi-elasticities are small: initiating organizational change as opposed to not doing so increases the employment of bluecollar workers by between 1.3 and 1.8 percent, although the effect is greater for the whitecollar aggregate at just under 9 percent. As far as the other variables are concerned there are scarcely any qualitative differences between the results for the restricted and full manufacturing samples. As expected, these and other differences (in magnitude) are explained by the reduction in sample size. (Results for the restricted manufacturing sample net of the organizational change variable are available on request.)

Stated baldly, the bottom lines from this empirical inquiry are fourfold. First, for manufacturing if not services, the own wage-elasticity of unskilled workers does not appear to be larger in absolute magnitude than that of skilled and yet more highly skilled groups. Second, capital and all the various skill categories seem to be complements in production. Third, (manufacturing) employment is increasing in export share. Finally, investing in technology and introducing organizational change are again productive of employment across the board. 


\section{Interpretation}

Our analysis has used information on 1,171 manufacturing plants covering on average 360,000 employees (and 174 service sector establishments covering some 49,000 employees), and has deployed one of the longest panels of which we are aware. Our findings differ somewhat from those reported in the literature in a number of respects. Chief among these is the absence of the familiar hierarchy in the own-wage elasticities by skill group (e.g. FitzRoy and Funke, 1998), at least for manufacturing. It may be objected that our findings for manufacturing could reflect inaccuracy in the identification of skill. Although our subsequent experimentation using education levels and qualifications to define blue-collar skill groups in manufacturing proved abortive (because of limited numbers of workers in the highest category), we were able to obtain a common measure of skill across sectors using the occupational breakdown suggested by Bauer and Bender (2004). Estimates based on these alternative skill definitions for manufacturing are reported in Table 8. It can be seen that our previous results hold up rather well. The largest changes are recorded for the highest skill group, which now contains most of the white-collar workers. The results for manufacturing based on employer skill definitions seem reasonably robust therefore. And, interestingly, the findings for the technology variables provide some support for biased technological change. (Although the results for services are also similar to those reported earlier, we do not cite them here mainly because the sample is now three times as large as before.)

(Table 8 near here)

Issues of hierachy in these elasticities notwithstanding, our estimates of the unskilled worker own-wage elasticity are always well determined, and are particularly strong in the case of services. Within manufacturing, unskilled workers emerge as substitutes in production for more skilled workers, among the ranks of which there is however only very weak evidence of complementarity. For services, on the other hand, there is little evidence that unskilled and skilled (and yet more skilled) workers are affected by each other's wage. In 
both sectors, some strong substitute relationships between the composite skill groups and the more narrowly defined categories again suggest that further disaggregation is in order.

Complementarity between capital and the various skill categories is stronger than in previous research using the LIAB (e.g. Bellmann and Schank, 2000; Kölling and Schank, 2002). However, such studies use either a cross section of data or at best a short panel. Note also that, with the exception of the composite groups, our estimates of the labor elasticities with respect to capital fall within a narrow range.

Increased trade does not appear to have adverse consequences for any skill group. That is to say the labor elasticities with respect to export share are not only uniformly positive but also well determined throughout. The estimated elasticities for unskilled blue-collar workers are smaller than for their skilled counterparts but the magnitudes are small for all blue-collar groups. But we would caution that the establishment panel does not contain information on the other side of the trade coin - imports - and so one cannot conclude in particular that trade is benign for low-skilled groups.

Perhaps most at odds with previous research, however, are our findings for technology. We find no evidence suggestive of skill-biased technical change insofar as this is captured by our two indicators. That is to say, neither upgrading to state-of-the-art equipment nor investing in Information technology has negative consequences for any of our narrowlydefined skill categories. Interestingly, the technology findings carry over to organizational change, which innovations are seemingly associated with modest increases in employment across the skill groups in manufacturing industry. In sum, the semi-elasticities are positive and statistically significant throughout. These results are also consistent with the results for the capital stock.

Our principal finding nevertheless resides in the estimated own-wage elasticities for unskilled workers. We have found that a 10 percent fall in the wages of unskilled workers would translate into a 5 increase in the demand for blue-collar workers in manufacturing and, 
more controversially, into a 21 percent increase in that of unskilled white-collar employees in services. If, as it is conventional to argue, rigid wages lie at the heart of the German employment problem, our estimates may suggest that one first-pass policy solution may lie in subsidizing unskilled work. To establish the effect of wage subsidies on unskilled worker unemployment, some additional assumption regarding the elasticity of wages with respect to unemployment is of course required (see Cahuc and Zylberberg, 2004, pp. 663-664). 


\section{Endnotes}

${ }^{1}$ We shall impute wages above the ceiling (see below).

2 The Panel survey is based on the employment statistics via the establishment identifier. As a result, the panel only includes establishments with at least one employee covered by social security.

${ }^{3}$ In a subset of estimates using this variable (see Table 7 below), since the Establishment Panel measures organizational change over a two-year interval we chose to use data from 1995 to impute values for the years 1993 and 1994 (thus dropping 1995), data from 1998 to impute values for 1996 and 1997, data from 2000 to impute values for 1998 and 1999, and finally data from 2001 to impute a value for 2000 (dropping 2001). In other words, for specifications using the organizational change argument we lose three years of data, including 2002 for which there was no organizational change question in the Establishment Panel.

${ }^{4}$ The questions concern the legal form of the firm and the denition of business volume. We excluded two such legal forms \{'Körperschaft des öffentlichen Rechts' and 'Sonstige Rechtsform (z.B. Verein, Genossenschaft)'\} as well as those units that defined their business volume in terms of budget rather than sales.

${ }^{5}$ Following Bauer and Bender (2004), we also experimented with an occupational-based representation of the workforce, wherein workers were classified into just three categories unskilled, skilled, and highly skilled - notwithstanding their white- or blue-collar status. The results of this exercise are briefly reported on in section VI below.

${ }^{6}$ An alternative representation of the technology is given by the Translog cost function (Christenson, Jorgenson, and Lau, 1973), which also can be viewed as a local second-order approximation of an arbitrary cost function. In this case, the factor shares rather than the conditional factor demands are linear in the relevant parameters of the cost function. The resulting system of cost share equations can also be estimated by the SUR technique described below.

${ }^{7}$ Rationalization of this approach in the context of labor demand estimation can be found in Bond and Reenen (2006).

${ }^{8}$ They can also be used to obtain more direct measures of skill-biased technological change (SBTC) than a trend term added to the regression.

${ }^{9}$ We selected the cluster option of the intreg-estimator provided in Stata. Our imputation procedure, based on the predicted wage plus an error term, also guarantees that the imputed wage is never below the ceiling. Results are available from the authors on request. We also experimented with alternative imputation methods. The results of imputations from estimating 
one wage equation per year across all skill categories for the manufacturing and service sectors are given in Appendix Tables 2 and 3, respectively. As can be seen, the results are similar to those obtained in text Tables 4 and 5 with the main differences being confined to the highly skilled.

${ }^{10}$ We should note that there are disparities between the sum of employees obtained from the employment statistics and the total given in the establishment panel. Where these amounted to 20 percent or more we chose to exclude the plant from the sample, treating the establishment identifier as flawed.

${ }^{11}$ Specifically, panel survey respondents are asked to estimate the percentage share of total sales represented by materials cost, so that multiplying sales volume by 1 minus this share yields value added.

12 Respondents in the Establishment Panel survey are asked to rate the technical condition of the plant's equipment compared with that of other firms in the industry/sector along a Likert scale where 1 indicates "state-of-the-art" (auf dem neuesten stand) equipment and 5 indicates “obsolete” equipment (völlig veraltet). In forming a modern technology dummy, we grouped categories 1 and 2 . 


\section{References}

Addison, John, Thorsten Schank, Claus Schnabel, and Joachim Wagner. 2003. "Works Councils in the Production Process.” Discussion Paper No. 812. Bonn: Institute for the Study of Labor/IZA, June.

Bauer, Thomas K., and Stefan Bender. 2004. “Technological Change, Organizational Change, and Job Turnover.” Labour Economics 11:265-291.

Bellmann, Lutz, and Thorsten Schank. 2000. "Innovations, Wages and Demand for Heterogeneous Labor: New Evidence from a Matched Employer-Employee Data-Set.” Discussion Paper No. 112. Bonn: Institute for the Study of Labor/IZA, February.

Bender, Stefan, Annette Haas, and Christoph Klose. 2000. “The IAB Employment Subsample, 1975-1995.” Schmollers Jahrbuch 120: 649-662.

Berndt, Ernst, and Laurits R. Christensen. 1974. "Testing for the Existence of a Consistent Aggregate Index of Labor Inputs.” American Economic Review 64 (June): 391-404.

Bond, Stephen R., and John van Reenen. 2006. "Microeconometric Models of Investment and Employment.” In James J. Heckman, and Edward E. Leamer (eds.), Handbook of Econometrics, Volume 6. Amsterdam and New York: Elsevier (forthcoming).

Cahuc, Pierre, and André Zylberberg. 2004. Labor Economics.Cambridge, MA, and London: The MIT Press.

Christensen Laurits R., Dale W. Jorgenson, Lawrence J. Lau. 1973. "Transcendental Logarithmic Production Frontiers. Review of Economics and Statistics 55(February): 28-45.

Diewert, W. Erwin. 1971. “An Application of the Shephard Duality Theorem: A Generalized Leontief Production Function.” Journal of Political Economy 79 (May-June): 481-507.

Falk, Martin, and Katja Seim. 1999. “Workers' Skill Level and Information Technology: Evidence from German Service Firms.” In Lutz Bellmann and Viktor Steiner (eds.), Panelanalysen zu Lohnstruktur, Qualifikation und Beshäftigungsdynamik. Beiträge zur Arbeitsmarkt- und Berufsforschung. Nuremberg: Bundesanstalt für Arbeit, pp. 79-116.

Fitzenberger, Bernd.1999a. "International Trade and the Skill Structure of Wages and Employment in West Germany.” Jahrbücher für Nationalökonomie und Statistik 219: 67-89.

Fitzenberger, Bernd.1999b. Wages and Employment across Skill Groups: An Analysis for West Germany. Heidelberg: Physica Verlag

FitzRoy, Felix, and Michael Funke. 1998. “Skills, Wages, and Employment in East and West Germany.” Regional Studies 32 (July): 459-467.

Kölling, Arnd. 2000. “The IAB Establishment Panel.” Schmollers Jahrbuch 120: 291-300. 
Kölling, Arnd, and Thorsten Schank. 2002. "Skill-Biased Technological Change, International Trade and the Wage Structure.” Discussion Paper No. 14, Lehrstuhl für Volkswirtschaftslehre/Arbeitsmarkt- und Regioalpolitik, Friedrich-Alexander-Universität Erlangen-Nürnberg, September.

Lindbeck, Assar, and Dennis J. Snower. 2000. “Multitask Learning and the Reorganization of Work: From Tayloristic to Holistic Organization.” Journal of Labor Economics 18 (July): 353-376.

Wolf, Elke, and Thomas Zwick. 2002. "Reassessing the Impact of High Performance Workplaces.” Discussion Paper No. 02-07, Centre for European Economic Research/ZEW, Mannheim. 
Table 1: Descriptive Statistics of the Regression Sample, Manufacturing

\begin{tabular}{|c|c|c|c|c|}
\hline \multirow[b]{2}{*}{ Variable } & \multicolumn{2}{|c|}{ Full sample } & \multicolumn{2}{|c|}{ Reduced sample } \\
\hline & Mean & Std. dev. & Mean & Std. dev. \\
\hline \multicolumn{5}{|l|}{ Number of employees: } \\
\hline \multicolumn{5}{|l|}{ Blue-collar workers } \\
\hline -unskilled & 264 & 523 & 288 & 506 \\
\hline -skilled & 218 & 470 & 232 & 471 \\
\hline -highly skilled & 20 & 57 & 22 & 53 \\
\hline White-collar workers & 234 & 461 & 252 & 463 \\
\hline \multirow{2}{*}{\multicolumn{5}{|c|}{$\begin{array}{l}\text { Daily wage (in DM): } \\
\text { Blue-collar workers }\end{array}$}} \\
\hline & & & & \\
\hline - unskilled & 148 & 24 & 145 & 23 \\
\hline - skilled & 170 & 23 & 167 & 22 \\
\hline - highly skilled & 236 & 28 & 232 & 27 \\
\hline White-collar workers & 215 & 29 & 211 & 28 \\
\hline Output (mill. DM) & 314 & 709 & 322 & 644 \\
\hline Capital (mill. DM) & 33. & 97.7 & 34.6 & 85.3 \\
\hline Export share & 0.29 & 0.26 & 0.29 & 0.26 \\
\hline Index of technology & 0.74 & 0.44 & 0.75 & 0.44 \\
\hline Investment in IT & 0.80 & 0.40 & 0.80 & 0.40 \\
\hline Investment in other units & 0.90 & 0.31 & 0.91 & 0.28 \\
\hline Investment in buildings & 0.36 & 0.48 & 0.37 & 0.48 \\
\hline Organizational change & & & 0.85 & 0.36 \\
\hline $\mathrm{n}$ & 4982 & & 2649 & \\
\hline Establishments & 1171 & & 688 & \\
\hline
\end{tabular}

Notes: A description of the variables is provided in Appendix Table 1. The 'reduced sample' is obtained when dropping all establishments in which the organizational change variable is missing. 
Table 2: Descriptive Statistics of the Regression Sample, Services

\begin{tabular}{|c|c|c|c|c|}
\hline \multirow[b]{2}{*}{ Variables } & \multicolumn{2}{|c|}{ Full sample } & \multicolumn{2}{|c|}{ Sub-sample } \\
\hline & Mean & Std. dev. & Mean & Std. dev. \\
\hline \multicolumn{5}{|l|}{ Number of employees: } \\
\hline \multicolumn{5}{|l|}{ White-collar workers } \\
\hline -unskilled & 19 & 36 & 24 & 47 \\
\hline -skilled & 330 & 432 & 305 & 509 \\
\hline -highly skilled & 105 & 210 & 67 & 178 \\
\hline Blue-collar workers & 225 & 597 & 345 & 837 \\
\hline \multicolumn{5}{|l|}{ Daily wage (in DM): } \\
\hline \multicolumn{5}{|l|}{ White-collar workers } \\
\hline - unskilled & 156 & 32 & 161 & 36 \\
\hline - skilled & 176 & 26 & 182 & 30 \\
\hline - highly skilled & 257 & 47 & 250 & 48 \\
\hline Blue-collar workers & 142 & 25 & 148 & 28 \\
\hline Output (mill. DM) & 224 & 518 & 285 & 635 \\
\hline Capital (mill. DM) & 39. & 118 & 51. & 158 \\
\hline Index of technology & 0.69 & 0.46 & 0.76 & 0.43 \\
\hline Investment in IT & 0.83 & 0.38 & 0.81 & 0.39 \\
\hline Investment in other units & 0.78 & 0.42 & 0.78 & 0.42 \\
\hline Investment in buildings & 0.53 & 0.50 & 0.49 & 0.50 \\
\hline Organizational change & & & 0.82 & 0.38 \\
\hline $\mathrm{n}$ & 1427 & & 654 & \\
\hline Establishments & 368 & & 174 & \\
\hline
\end{tabular}

Notes: See Table 1. The 'sub-sample' is based on a further cut of the services data designed to remove remaining not-for-profit units; see the text and footnote 4. 
Table 3: Constrained SUR Parameter Estimates for Heterogeneous Labor Demand Equations Derived from a Generalized Leontief Cost Function, Manufacturing

\begin{tabular}{|c|c|c|c|c|c|c|c|c|}
\hline & \multicolumn{6}{|c|}{ Blue-collar-workers } & \multirow{2}{*}{\multicolumn{2}{|c|}{$\begin{array}{l}\text { White-collar } \\
\text { workers }\end{array}$}} \\
\hline & \multicolumn{2}{|c|}{ Unskilled } & \multicolumn{2}{|c|}{ Skilled } & \multicolumn{2}{|c|}{ Highly skilled } & & \\
\hline$\sqrt{w_{2} / w_{1}}$ & 1.09e-06 & $* * *$ & & & & & & \\
\hline$\sqrt{w_{3} / w_{1}}$ & $\begin{array}{r}2.00 \mathrm{e}-07 \\
{[2.90]}\end{array}$ & $* * *$ & & & & & & \\
\hline$\sqrt{w_{4} / w_{1}}$ & $\begin{array}{r}-5.27 \mathrm{e}-07 \\
{[2.09]}\end{array}$ & $* *$ & & & & & & \\
\hline$\sqrt{w_{1} / w_{2}}$ & & & $\begin{array}{r}1.09 \mathrm{e}-06 \\
{[5.79]}\end{array}$ & $* * *$ & & & & \\
\hline$\sqrt{w_{3} / w_{2}}$ & & & $\begin{array}{r}-2.38 \mathrm{e}-08 \\
{[0.31]}\end{array}$ & & & & & \\
\hline$\sqrt{w_{4} / w_{2}}$ & & & $\begin{array}{r}1.66 \mathrm{e}-07 \\
{[0.83]}\end{array}$ & & & & & \\
\hline$\sqrt{w_{1} / w_{3}}$ & & & & & $\begin{array}{r}2.00 \mathrm{e}-07 \\
{[2.90]}\end{array}$ & & & \\
\hline$\sqrt{w_{2} / w_{3}}$ & & & & & $\begin{array}{r}-2.38 \mathrm{e}-08 \\
{[0.31]}\end{array}$ & & & \\
\hline$\sqrt{w_{4} / w_{3}}$ & & & & & $\begin{array}{r}-8.65 \mathrm{e}-08 \\
{[1.15]}\end{array}$ & & & \\
\hline$\sqrt{w_{1} / w_{4}}$ & & & & & & & $\begin{array}{r}-5.27 e-07 \\
{[2.09]}\end{array}$ & $* *$ \\
\hline$\sqrt{w_{2} / w_{4}}$ & & & & & & & $\begin{array}{r}1.66 \mathrm{e}-07 \\
{[0.83]}\end{array}$ & \\
\hline$\sqrt{w_{3} / w_{4}}$ & & & & & & & $\begin{array}{r}-8.65 \mathrm{e}-08 \\
{[1.15]}\end{array}$ & \\
\hline Output & $\begin{array}{r}-9.49 e-16 \\
{[15.27]}\end{array}$ & $* * *$ & $\begin{array}{r}-9.34 \mathrm{e}-16 \\
{[16.35]}\end{array}$ & $* * *$ & $\begin{array}{r}-2.57 e-17 \\
{[3.29]}\end{array}$ & $* * *$ & $\begin{array}{r}-5.11 e-15 \\
{[13.71]}\end{array}$ & $* * *$ \\
\hline Capital & $\begin{array}{r}3.16 \mathrm{e}-06 \\
{[51.51]}\end{array}$ & $* * *$ & $\begin{array}{r}2.66 \mathrm{e}-06 \\
{[47.26]}\end{array}$ & $* * *$ & $\begin{array}{r}3.41 \mathrm{e}-07 \\
{[14.07]}\end{array}$ & $* * *$ & $\begin{array}{r}0.0000123 \\
\text { [33.53] }\end{array}$ & $* * *$ \\
\hline Export share & $\begin{array}{r}51.29 \\
{[10.14]}\end{array}$ & $* * *$ & $\begin{array}{r}68.98 \\
{[20.37]}\end{array}$ & $* * *$ & $\begin{array}{r}1.39 \\
{[2.99]}\end{array}$ & $* * *$ & $\begin{array}{r}414.35 \\
{[18.74]}\end{array}$ & $* * *$ \\
\hline Index of technology & $\begin{array}{r}7.51 \\
{[13.91]}\end{array}$ & $* * *$ & $\begin{array}{r}4.68 \\
{[6.88]}\end{array}$ & $* * *$ & $\begin{array}{r}1.02 \\
{[10.91]}\end{array}$ & $* * *$ & $\begin{array}{r}9.39 \\
{[2.11]}\end{array}$ & $* *$ \\
\hline Investment in IT & $\begin{array}{r}4.949 \\
{[9.43]}\end{array}$ & $* * *$ & $\begin{array}{l}3.556 \\
{[7.38]}\end{array}$ & $* * *$ & $\begin{array}{r}0.629 \\
{[9.50]}\end{array}$ & $* * *$ & $\begin{array}{r}13.709 \\
{[4.35]}\end{array}$ & $* * *$ \\
\hline Investment in other units & $\begin{array}{l}4.137 \\
{[6.92]}\end{array}$ & $* * *$ & $\begin{array}{l}2.997 \\
{[5.46]}\end{array}$ & $* * *$ & $\begin{array}{c}0.217 \\
{[2.88]}\end{array}$ & $* * *$ & $\begin{array}{r}15.674 \\
{[4.37]}\end{array}$ & $* * *$ \\
\hline Investment in buildings & $\begin{array}{l}-1.517 \\
{[2.19]}\end{array}$ & $* *$ & $\begin{array}{l}-1.963 \\
{[3.08]}\end{array}$ & $* * *$ & $\begin{array}{l}-0.438 \\
{[5.02]}\end{array}$ & $* * *$ & $\begin{array}{r}-5.564 \\
{[1.34]}\end{array}$ & \\
\hline
\end{tabular}

Notes: $|\mathrm{t}|$-statistics in brackets. ${ }^{* * *}, * *, *$ denote statistical significance at the $.01, .05$. and .10 levels, respectively. Parameter estimates were obtained from a (constrained) SUR regression after a withinplant transformation of the data. Regressions also include year dummies. $\sqrt{w_{i} / w_{j}}$ denotes the square root of relative wage of skill category $i$ with respect to category $j, i \neq j, i, j=1,2,3,4$, where subscripts 1, 2, 3, and 4 denote unskilled, skilled, and highly skilled blue-collar workers and white- 
collar workers, respectively. The parameters of the $\sqrt{w_{i} / w_{j}}$ variables were constrained to be equal to the parameters of the corresponding variables $\sqrt{w_{j} / w_{i}}$. The remaining variables in the specification, including the dependent variable, were divided by the output level. The number of observations (establishments) is 4,982 (1,171). 
Table 4: Constrained SUR Parameter Estimates for Heterogeneous Labor Demand Equations Derived from a Generalized Leontief Cost Function, Services Sub-sample

\begin{tabular}{|c|c|c|c|c|c|c|c|c|}
\hline & \multicolumn{6}{|c|}{ White-collar-workers } & \multirow{2}{*}{\multicolumn{2}{|c|}{$\begin{array}{l}\text { Blue-collar } \\
\text { workers }\end{array}$}} \\
\hline & \multicolumn{2}{|c|}{ Unskilled } & \multicolumn{2}{|c|}{ Skilled } & \multicolumn{2}{|c|}{ Highly skilled } & & \\
\hline$\sqrt{w_{2} / w_{1}}$ & $-2.81 \mathrm{e}-08$ & & & & & & & \\
\hline$\sqrt{w_{3} / w_{1}}$ & $\begin{array}{r}5.24 \mathrm{e}-08 \\
{[1.12]}\end{array}$ & & & & & & & \\
\hline$\sqrt{w_{4} / w_{1}}$ & $\begin{array}{r}3.26 \mathrm{e}-07 \\
{[2.34]}\end{array}$ & $* *$ & & & & & & \\
\hline$\sqrt{w_{1} / w_{2}}$ & & & $\begin{array}{r}-2.81 \mathrm{e}-08 \\
{[0.20]}\end{array}$ & & & & & \\
\hline$\sqrt{w_{3} / w_{2}}$ & & & $\begin{array}{r}-5.98 \mathrm{e}-07 \\
{[2.36]}\end{array}$ & $* *$ & & & & \\
\hline$\sqrt{w_{4} / w_{2}}$ & & & $\begin{array}{r}2.01 \mathrm{e}-06 \\
{[2.01]}\end{array}$ & ** & & & & \\
\hline$\sqrt{w_{1} / w_{3}}$ & & & & & $\begin{array}{r}5.24 \mathrm{e}-08 \\
{[1.12]}\end{array}$ & & & \\
\hline$\sqrt{w_{2} / w_{3}}$ & & & & & $\begin{array}{r}-5.98 \mathrm{e}-07 \\
{[2.36]}\end{array}$ & & & \\
\hline$\sqrt{w_{4} / w_{3}}$ & & & & & $\begin{array}{r}4.11 \mathrm{e}-07 \\
{[1.19]}\end{array}$ & & & \\
\hline$\sqrt{w_{1} / w_{4}}$ & & & & & & & $\begin{array}{r}3.26 \mathrm{e}-07 \\
{[2.34]}\end{array}$ & \\
\hline$\sqrt{w_{2} / w_{4}}$ & & & & & & & $\begin{array}{r}2.01 \mathrm{e}-06 \\
{[2.01]}\end{array}$ & $* *$ \\
\hline$\sqrt{w_{3} / w_{4}}$ & & & & & & & $\begin{array}{r}4.11 \mathrm{e}-07 \\
{[1.19]}\end{array}$ & \\
\hline Output & $\begin{array}{r}-1.90 \mathrm{e}-18 \\
{[0.28]}\end{array}$ & & $\begin{array}{r}-7.69 \mathrm{e}-17 \\
{[0.97]}\end{array}$ & & $\begin{array}{r}-2.25 e-17 \\
{[0.89]}\end{array}$ & & $\begin{array}{r}-9.67 e-17 \\
{[0.65]}\end{array}$ & \\
\hline Capital & $\begin{array}{r}1.20 \mathrm{e}-07 \\
{[7.20]}\end{array}$ & $* * *$ & $\begin{array}{r}1.53 \mathrm{e}-06 \\
{[7.74]}\end{array}$ & $* * *$ & $\begin{array}{r}4.76 \mathrm{e}-07 \\
{[7.53]}\end{array}$ & $* * *$ & $\begin{array}{r}2.41 \mathrm{e}-06 \\
{[6.50]}\end{array}$ & $* * *$ \\
\hline \multicolumn{9}{|l|}{ Export share } \\
\hline Index of technology & $\begin{array}{l}2.900 \\
{[9.43]}\end{array}$ & $* * *$ & $\begin{array}{r}65.21 \\
{[17.98]}\end{array}$ & $* * *$ & $\begin{array}{r}15.51 \\
{[13.36]}\end{array}$ & $* * *$ & $\begin{array}{l}50.81 \\
{[7.47]}\end{array}$ & $* * *$ \\
\hline Investment in IT & $\begin{array}{c}2.047 \\
{[7.67]}\end{array}$ & $* * *$ & $\begin{array}{c}19.98 \\
{[6.36]}\end{array}$ & $* * *$ & $\begin{array}{r}9.81 \\
{[9.76]}\end{array}$ & $* * *$ & $\begin{array}{r}-9.63 \\
{[1.64]}\end{array}$ & \\
\hline Investment in other units & $\begin{array}{c}0.197 \\
{[0.61]}\end{array}$ & & $\begin{array}{r}-17.35 \\
{[4.53]}\end{array}$ & $* * *$ & $\begin{array}{r}-2.51 \\
{[2.04]}\end{array}$ & $* *$ & $\begin{array}{r}3.96 \\
{[0.55]}\end{array}$ & \\
\hline Investment in buildings & $\begin{array}{r}3.71 \\
{[10.25]}\end{array}$ & $* * *$ & $\begin{array}{r}45.05 \\
{[10.55]}\end{array}$ & $* * *$ & $\begin{array}{r}15.33 \\
{[11.21]}\end{array}$ & $* * *$ & $\begin{array}{r}47.24 \\
{[5.90]}\end{array}$ & $* * *$ \\
\hline
\end{tabular}

Notes: See Table 3. But observe that here, unlike Table 3, the subscripts $1,2,3$, and 4 denote unskilled, skilled, and highly skilled white-collar workers and blue-collar workers, respectively. The number of observations (establishments) is 654 (174). 
Table 5: Employment Elasticities for Different Skill Groups, Manufacturing (within-plant estimation)

\begin{tabular}{|c|c|c|c|c|c|c|c|c|}
\hline \multirow{3}{*}{ Elasticities } & \multicolumn{6}{|c|}{ Blue-collar workers } & \multirow{2}{*}{\multicolumn{2}{|c|}{$\begin{array}{l}\text { White-collar } \\
\text { workers }\end{array}$}} \\
\hline & \multicolumn{2}{|c|}{ Unskilled } & \multicolumn{2}{|c|}{ Skilled } & \multicolumn{2}{|c|}{ Highly skilled } & & \\
\hline & & & & & & & & \\
\hline $\begin{array}{l}\text { Wages: } \\
\text { Blue-collar workers }\end{array}$ & & & & & & & & \\
\hline -Unskilled & -0.472 & $* * *$ & 0.735 & $* * *$ & 1.220 & $* * *$ & -0.293 & $* *$ \\
\hline -Skilled & 0.700 & $* * *$ & -0.849 & $* * *$ & -0.155 & & 0.099 & \\
\hline -Highly skilled & 0.151 & $* * *$ & -0.020 & & -0.430 & & -0.061 & \\
\hline White-collar workers & -0.378 & $* *$ & 0.134 & & -0.635 & & 0.254 & \\
\hline Output & 0.238 & & 0.854 & $* *$ & 0.611 & & -4.814 & $* * *$ \\
\hline Capital & 0.403 & $* * *$ & 0.411 & $* * *$ & 0.561 & $* * *$ & 1.773 & $* * *$ \\
\hline Export share & 0.056 & $* * *$ & 0.091 & $* * *$ & 0.020 & $* * *$ & 0.512 & $* * *$ \\
\hline \multicolumn{9}{|l|}{ Semi-elasticities } \\
\hline Index of technology. & 0.029 & $* * *$ & 0.021 & $* * *$ & 0.050 & $* * *$ & 0.040 & $* *$ \\
\hline Investment in IT & 0.019 & *** & 0.016 & $* * *$ & 0.031 & $* * *$ & 0.059 & $* * *$ \\
\hline Investment in other units & 0.016 & $* * *$ & 0.014 & $* * *$ & 0.011 & $* * *$ & 0.067 & $* * *$ \\
\hline Investment in buildings & -0.006 & $* *$ & -0.009 & $* * *$ & -0.021 & $* * *$ & -0.024 & \\
\hline
\end{tabular}

Notes: ***, **, * denote statistical significance at the .01, .05. and .10 levels, respectively. The elasticities are obtained from the parameter estimates of a (constrained) SUR regression after a withinplant transformation of the data. The corresponding heterogeneous labor demand equations have been derived from a Generalized Leontief cost function. The number of observations (establishments) is $4,982(1,171)$. 
Table 6: Employment Elasticities for Different Skill Groups, Services (within-plant estimation; subsample)

\begin{tabular}{|c|c|c|c|c|c|c|c|c|}
\hline & \multicolumn{6}{|c|}{ White-collar workers } & \multirow{2}{*}{\multicolumn{2}{|c|}{$\begin{array}{l}\text { Blue-collar } \\
\text { workers }\end{array}$}} \\
\hline & \multicolumn{2}{|c|}{ Unskilled } & \multicolumn{2}{|c|}{ Skilled } & \multicolumn{2}{|c|}{ Highly skilled } & & \\
\hline \multicolumn{9}{|l|}{ Elasticities } \\
\hline \multicolumn{9}{|l|}{ Wages: } \\
\hline Unskilled & -2.086 & $* * *$ & -0.012 & & 0.089 & & 0.141 & $* *$ \\
\hline Skilled & -0.180 & & -0.508 & & -1.086 & $* *$ & 0.926 & $* *$ \\
\hline Highly skilled & 0.392 & & -0.328 & $* *$ & 0.326 & & 0.221 & \\
\hline Blue-collar workers & 1.874 & $* *$ & 0.849 & $* *$ & 0.671 & & -1.288 & $* *$ \\
\hline Output & 4.159 & $* * *$ & 0.976 & & -0.706 & & 2.530 & $* *$ \\
\hline Capital & 0.262 & $* * *$ & 0.260 & $* * *$ & 0.367 & $* * *$ & 0.362 & $* * *$ \\
\hline \multicolumn{9}{|l|}{ Semi-elasticities } \\
\hline Index of technology & 0.122 & $* * *$ & 0.214 & $* * *$ & 0.231 & $* * *$ & 0.147 & $* * *$ \\
\hline Investment in IT & 0.086 & $* * *$ & 0.065 & $* * *$ & 0.146 & $* * *$ & -0.028 & \\
\hline Investment in other units & 0.008 & & -0.057 & $* * *$ & -0.037 & $* *$ & 0.011 & \\
\hline Investment in buildings & 0.156 & $* * *$ & 0.148 & $* * *$ & 0.228 & $* * *$ & 0.137 & $* * *$ \\
\hline
\end{tabular}

Notes: See Table 5. The number of observations (establishments) is 654 (174). 
Table 7: Employment Elasticities for Different Skill Groups, Manufacturing (within-plant estimation; reduced sample with the additional regressor 'organizational change')

Blue-collar workers

$\begin{array}{lcl} & & \\ \text { Unskilled } & \text { Skilled } & \text { Highly skilled } \\ \text { workers }\end{array}$

Elasticities

Wages:

Blue-collar workers

-Unskilled

-Skilled

-Highly skilled

White-collar workers

\begin{tabular}{|c|c|c|c|c|c|c|c|}
\hline-0.492 & $* *$ & 1.184 & $* * *$ & 1.945 & $* *$ & -0.658 & $* * *$ \\
\hline 1.096 & *** & -1.330 & $* * *$ & 0.015 & & 0.105 & \\
\hline 0.235 & ** & 0.002 & & 0.116 & & -0.197 & ** \\
\hline-0.839 & $* * *$ & 0.144 & & -2.077 & $* *$ & 0.750 & $* *$ \\
\hline 0.139 & & 1.754 & $* * *$ & -0.832 & & -5.794 & k* \\
\hline 0.599 & $* * *$ & 0.711 & $* * *$ & 0.354 & $* * *$ & 4.125 & k* \\
\hline 0.040 & *** & 0.073 & $* * *$ & 0.030 & $* * *$ & 0.366 & k* \\
\hline
\end{tabular}

\section{Semi-elasticities}

Index of technology

Investment in IT

\begin{tabular}{|c|c|c|c|c|c|c|c|}
\hline 0.040 & $* * *$ & 0.030 & $* * *$ & 0.054 & $* * *$ & 0.118 & $* * *$ \\
\hline 0.020 & $* * *$ & 0.015 & $* * *$ & 0.035 & *** & 0.043 & $* *$ \\
\hline 0.003 & & 0.013 & $* * *$ & 0.014 & $*$ & 0.024 & \\
\hline 0.018 & $* * *$ & -0.016 & $* * *$ & 0.002 & & -0.136 & $* * *$ \\
\hline 0.013 & $* * *$ & 0.018 & $* * *$ & 0.018 & $* *$ & 0.087 & $* * *$ \\
\hline
\end{tabular}

ther units

Investment in buildings

$0.013 * * *$

$0.018 * * *$

$0.018 * *$

Notes: See Table 5. The number of observations (establishments) is 2,649 (688). 
Table 8: Employment Elasticities for Different Skill Groups According to Occupation, Manufacturing (within-plant estimation)

\begin{tabular}{|c|c|c|c|c|c|c|}
\hline Elasticities & \multicolumn{2}{|c|}{ Unskilled } & \multicolumn{2}{|c|}{ Skilled } & \multicolumn{2}{|c|}{ Highly skilled } \\
\hline \multicolumn{7}{|l|}{ Wages: } \\
\hline - Unskilled & -0.496 & $* * *$ & 0.604 & $* * *$ & -0.006 & \\
\hline - Skilled & 0.501 & $* * *$ & -1.051 & $* * *$ & 0.606 & $* * *$ \\
\hline - Highly skilled & -0.004 & & 0.447 & $* * *$ & -0.600 & $* * *$ \\
\hline Output & 0.095 & & 0.687 & $* * *$ & -2.727 & $* * *$ \\
\hline Capital & 0.504 & $* * *$ & 0.677 & $* * *$ & 1.852 & $* * *$ \\
\hline Export share & 0.039 & $* * *$ & 0.069 & $* * *$ & 0.201 & $* * *$ \\
\hline \multicolumn{7}{|l|}{ Semi-elasticities } \\
\hline Index of technology. & 0.029 & $* * *$ & 0.029 & $* * *$ & 0.061 & $* * *$ \\
\hline Investment in IT & 0.004 & $* * *$ & 0.007 & $* *$ & 0.007 & $* * *$ \\
\hline Investment in other units & 0.015 & $* * *$ & 0.007 & $*$ & 0.008 & \\
\hline Investment in buildings & -0.019 & $* * *$ & -0.020 & $* * *$ & -0.060 & $* * *$ \\
\hline
\end{tabular}

Notes: See Table 5. The number of observations (establishments) is 4,982 $(1,171)$. 
Appendix Table 1: Description of the Variables

\begin{tabular}{|c|c|}
\hline Variable & Description \\
\hline Employee skill groups & $\begin{array}{l}\text { Employees in the raw administrative records were first classified into four groups: } \\
\text { three blue-collar worker categories (comprising the unskilled, skilled, and highly } \\
\text { skilled) and one aggregate white-collar category made up of all white-collar grades. } \\
\text { (The residual categories of home-workers, part-time workers, and apprentices were } \\
\text { dropped from the sample.) White-collar workers were then disaggregated into three } \\
\text { skill categories according to their education level: unskilled (individuals without a } \\
\text { completed apprenticeship and without an Abitur), skilled (individuals with a } \\
\text { completed apprenticeship and/or an Abitur), and highly skilled (individuals } \\
\text { possessing a college, polytechnic, or university degree). As noted in the text, for the } \\
\text { manufacturing sector analysis we used all three blue-collar skill categories and the } \\
\text { single white-collar aggregate; whereas in the service sector we deployed all three } \\
\text { white-collar categories and aggregated the blue-collar categories into a single } \\
\text { grouping. }\end{array}$ \\
\hline Wages & $\begin{array}{l}\text { Daily wage in DM. Information on individual wages in the administrative data is } \\
\text { right censored at the upper earnings limit for social security contributions. For such } \\
\text { individuals, the predicted wage was obtained using separate Tobit regressions of the } \\
\text { daily wage on age, gender, nationality, 3-digit occupational dummies, plant size, and } \\
\text { industry and year dummies. }\end{array}$ \\
\hline Output & Total sales in DM \\
\hline Capital & Sum of the current and the previous year's investment. \\
\hline Export share & The percentage share of exports in the establishment's annual turnover. \\
\hline Index of technology & $\begin{array}{l}\text { Modern technology dummy, assuming the value of } 1 \text { if the plant's equipment is either } \\
\text { state-of-the art or up-to-date compared with other firms in the same industry, } 0 \\
\text { otherwise. }\end{array}$ \\
\hline $\begin{array}{l}\text { Investment in information and } \\
\text { communication technology }\end{array}$ & $\begin{array}{l}\text { IT dummy, assuming the value of } 1 \text { if the establishment has invested during the } \\
\text { survey year in information and communication technology, } 0 \text { otherwise. }\end{array}$ \\
\hline Investment in other units & $\begin{array}{l}\text { Dummy variable assuming the value of } 1 \text { if the establishment has invested during the } \\
\text { survey year in other plant and equipment, } 0 \text { otherwise. }\end{array}$ \\
\hline Investment in buildings & $\begin{array}{l}\text { Dummy variable if the establishment has invested during the survey year in } \\
\text { buildings and real estate, } 0 \text { otherwise. }\end{array}$ \\
\hline Organizational change & $\begin{array}{l}\text { Dummy variable assuming the value of } 1 \text { if the establishment had (in the last two } \\
\text { years) reorganized by shifting responsibilities and decision making to lower levels in } \\
\text { the hierarchy, by setting up units with their own costs and results accounting, and by } \\
\text { introducing team work and self-governing work groups, etc. The organizational } \\
\text { change question was not asked in all waves of the establishment panel. The method } \\
\text { of interpolation used in the present treatment is documented in the text (footnote 3). }\end{array}$ \\
\hline
\end{tabular}

Notes: In the employee-employer matching procedure, all establishments employing less than 20 employees were dropped from the sample. Further, inclusion required that each establishment had at least 2 workers in each skill category. Finally, establishments in which the employer-employee match yielded a difference in employment levels of 20 percent or more were excised from the sample. 
Appendix Table 2: Employment Elasticities for Different Skill Groups Based on Imputations From One Wage Regression Per Year, Manufacturing (within-plant estimation).

Blue-collar workers

White-collar workers

Unskilled Skilled Highly skilled

\begin{tabular}{|c|c|c|c|c|c|c|c|c|}
\hline \multicolumn{9}{|l|}{ Elasticities } \\
\hline \multicolumn{9}{|l|}{ Wages: } \\
\hline \multicolumn{9}{|l|}{ Blue-collar workers } \\
\hline -Unskilled & -0.548 & $* * *$ & 0.717 & $* * *$ & 1.099 & $* * *$ & -0.204 & * \\
\hline -Skilled & 0.683 & $* * *$ & -0.698 & $* * *$ & 0.056 & & -0.019 & \\
\hline -Highly skilled & 0.139 & $* * *$ & 0.007 & & -0.400 & & -0.071 & $*$ \\
\hline White-collar workers & 0.273 & $*$ & -0.026 & & -0.755 & $*$ & 0.295 & \\
\hline Output & 0.392 & & 0.550 & * & 0.552 & & -4.900 & $* * *$ \\
\hline Capital & 0.403 & $* * *$ & 0.410 & $* * *$ & 0.561 & $* * *$ & 1.775 & $* * *$ \\
\hline Export share & 0.056 & $* * *$ & 0.091 & $* * *$ & 0.019 & $* * *$ & 0.512 & $* * *$ \\
\hline \multicolumn{9}{|l|}{ Semi-elasticities } \\
\hline Index of technology. & 0.029 & $* * *$ & 0.021 & $* * *$ & 0.050 & $* * *$ & 0.040 & $* *$ \\
\hline Investment in IT & 0.019 & $* * *$ & 0.016 & $* * *$ & 0.031 & $* * *$ & 0.059 & $* * *$ \\
\hline Investment in other units & 0.016 & $* * *$ & 0.014 & $* * *$ & 0.011 & $* * *$ & 0.067 & $* * *$ \\
\hline Investment in buildings & -0.006 & $* *$ & -0.009 & $* * *$ & -0.021 & $* * *$ & -0.024 & \\
\hline
\end{tabular}

Notes: See Table 5. The number of observations (establishments) is 4,888 $(1,169)$. 
Appendix Table 3: Employment Elasticities for Different Skill Groups Based on Imputations From One Wage Regression Per Year, Services (within-plant estimation).

\begin{tabular}{|c|c|c|c|c|c|c|c|c|}
\hline & \multicolumn{6}{|c|}{ White-collar workers } & \multirow{2}{*}{\multicolumn{2}{|c|}{$\begin{array}{l}\text { Blue-collar } \\
\text { workers }\end{array}$}} \\
\hline & \multicolumn{2}{|c|}{ Unskilled } & \multicolumn{2}{|c|}{ Skilled } & \multicolumn{2}{|c|}{ Highly skilled } & & \\
\hline \multicolumn{9}{|l|}{ Elasticities } \\
\hline \multicolumn{9}{|l|}{$\begin{array}{l}\text { Wages: } \\
\text { White-collar workers }\end{array}$} \\
\hline Unskilled & -2.112 & $* * *$ & -0.045 & & 0.179 & $* *$ & 0.150 & $* * *$ \\
\hline Skilled & -0.659 & & -0.703 & $*$ & -1.127 & ** & 1.180 & $* *$ \\
\hline Highly skilled & 0.769 & $* *$ & -0.335 & ** & 0.167 & & 0.253 & \\
\hline Blue-collar workers & 2.002 & $* * *$ & 1.083 & $* *$ & 0.781 & & -1.583 & $* * *$ \\
\hline Output & 4.245 & $* * *$ & 1.362 & $*$ & -0.394 & & 3.134 & $* * *$ \\
\hline Capital & 0.262 & $* * *$ & 0.258 & $* * *$ & 0.367 & $* * *$ & 0.363 & $* * *$ \\
\hline \multicolumn{9}{|l|}{ Semi-elasticities } \\
\hline Index of technology & 0.123 & $* * *$ & 0.214 & $* * *$ & 0.231 & $* * *$ & 0.147 & $* * *$ \\
\hline Investment in IT & 0.086 & $* * *$ & 0.066 & $* * *$ & 0.146 & $* * *$ & -0.028 & \\
\hline Investment in other units & 0.009 & & -0.057 & $* * *$ & -0.037 & $* *$ & 0.012 & \\
\hline Investment in buildings & 0.156 & $* * *$ & 0.148 & $* * *$ & 0.229 & $* * *$ & 0.137 & $* * *$ \\
\hline
\end{tabular}

Notes: See Table 5. The number of observations (establishments) is 654 (174). 